\title{
High levels of chorionic gonadotrophin attenuate insulin sensitivity and promote inflammation in adipocytes
}

\author{
Qinyun Ma*, Jianxia Fan ${ }^{1, *}$, Jiqiu Wang*, Shuai Yang ${ }^{1}$, Qing Cong ${ }^{2}$, Rui Wang, \\ Qianqian Lv, Ruixin Liu and Guang Ning
}

\begin{abstract}
Shanghai Key Laboratory for Endocrine Tumors and E-Institute of Shanghai Universities, Department of Endocrine and Metabolic Diseases, Shanghai Institute of Endocrinology and Metabolism, Shanghai Clinical Center for Endocrine and Metabolic Diseases, China National Clinical Research for Metabolic Diseases, Ruijin Hospital, Shanghai Jiaotong University School of Medicine, 197 Ruijin 2nd Road, Shanghai 200025, China ${ }^{1}$ Department of Obstetrics and Gynecology, International Peace Maternity and Child Health Hospital affiliated Shanghai Jiaotong University School of Medicine, 910 Hengshan Road, Shanghai 200030, China ${ }^{2}$ Department of Obstetrics and Gynecology, Obstetrics and Gynecology Hospital of Fudan University, 419 Fangxie Road, Shanghai 200011, China

*(Q Ma, J Fan and J Wang contributed equally to this work)
\end{abstract}

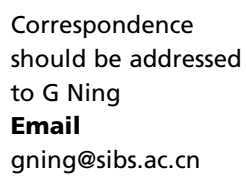

\begin{abstract}
Gestational diabetes mellitus (GDM) presents with moderate inflammation, insulin resistance and impaired glucose uptake, which may result from increased maternal fat mass and increased circulation of placental hormones and adipokines. In this study, we set out to test whether the surge in chorionic gonadotrophin (CG) secretion is a cause of inflammation and impaired insulin sensitivity in GDM. We first found that $\mathrm{LH} /$ chorionic gonadotrophin receptors (CG/LHR) were expressed at low levels in insulin-sensitive murine 3T3-L1 adipocytes and murine C2C12 myocytes. CG treatment not only directly reduced insulin-responsive gene expression, including that of glucose transporter 4 (GLUT4), but also impaired insulin-stimulated glucose uptake in 3T3-L1 cells. Moreover, CG treatment increased the expression of the proinflammatory cytokine monocyte chemotactic protein 1 (MCP1) and upregulated nuclear factor $\kappa$-light-chain-enhancer of activated B cells (NF- $\kappa$ B) activity in 3T3-L1 cells. Clinically, pregnant women who had higher CG levels and elevated MCP1 developed GDM. Above all, apart from prepregnancy BMI and MCP1 level, CG level was associated with abnormal glucose tolerance. In summary, our findings confirmed that higher CG levels in pregnancy possibly played a role in GDM development partly by impairing the functions of insulin, such those involved in as glucose uptake, while promoting inflammation in adipocyte.
\end{abstract}

Key Words

- chorionic gonadotrophin (CG)

- gestational diabetes mellitus (GDM)

- 3T3-L1 cells

- insulin resistance

- proinflammation

\section{Introduction}

Gestational diabetes mellitus (GDM) affects $2-5 \%$ of pregnant women (Gilmartin et al. 2008), which is characterised by maternal peripheral insulin resistance (IR) and increased inflammation. Increased amounts of placental hormones, such as progesterone, cortisol, prolactin and placental lactogen, induce IR (Ryan \& Enns 1988). Moreover, increased maternal fat mass and elevated adipokine also play a role (Catalano et al. 1998, Kirwan et al. 2002). 
Results of previous studies indicated that moderate inflammation during pregnancy is correlated with IR and GDM (Wolf et al. 2004, Kinalski et al. 2005, de Castro et al. 2011).

Chorionic gonadotrophin (CG) is produced by the placenta and binds to the luteinising hormone/chorionic gonadotrophin receptor (CG/LHR), a transmembrane glycoprotein receptor that belongs to the G-protein-coupled receptor superfamily (Loosfelt et al. 1989, McFarland et al. 1989). CG is essential for the maintenance of human pregnancy by stimulating progesterone production in the corpus luteum. Blood CG levels are known to exponentially increase during the first 2 months of pregnancy (Cole 2010). Furthermore, elevated CG levels are also a useful predictor of pregnancy-related diseases, including gestational hypertension, preeclampsia, intrauterine growth restriction and GDM (Heikkila et al. 2001, Merviel et al. 2001, Androutsopoulos et al. 2009), which indicates that CG may have extragonadal functions. Accumulating evidence indicates that several non-gonadal tissues contain low levels of functional CG/LHR and that the non-gonadal actions of LH/CG are physiologically important (Rao 2001, Abdallah et al. 2004). Results described in previous reports have indicated that CG/LHR is expressed in human primary adipocytes and 3T3-L1 adipocytes, CG treatment influences preadipocyte differentiation and leptin secretion (Sivan et al. 1998, Dos Santos et al. 2007). However, up till now, it remains unclear whether the surge in CG secretion with GDM contributes to IR and inflammation through functional CG/LHR in non-gonadal tissues. In this study, we confirmed that CG can influence insulin sensitivity and induce inflammation by the CG/LHR expressed in adipocytes, which possibly contributes to GDM development.

\section{Materials and methods}

\section{Patients}

In this study, a standard $75 \mathrm{~g}$ oral glucose tolerance test (OGTT) was performed on pregnant women with fasting plasma glucose of $4.4 \mathrm{mmol} / \mathrm{l}$ or greater at 24-28 weeks of gestation. Participants who visited peripheral antenatal clinics and underwent an OGTT were selected according to the inclusion criteria as follows: i) pregnant Han Chinese women; ii) 25-35 years old; iii) primipara and iv) singleton pregnancy. Exclusion criteria included the following: i) trophoblastic diseases; ii) triploidies and iii) multiple pregnancies. The diagnosis of GDM was based on the new criteria established by the American Diabetes Association (2011). GDM was diagnosed when one or more of the following plasma levels were abnormal: fasting plasma glucose level $\geq 5.1 \mathrm{mmol} / \mathrm{l} ; 1 \mathrm{~h}$ glucose level $\geq 10.0 \mathrm{mmol} / \mathrm{l}$; or $2 \mathrm{~h}$ glucose level $\geq 8.5 \mathrm{mmol} / \mathrm{l}$. A total of 42 patients with GDM and 47 controls with normal glucose tolerance (NGT) as planned were enrolled in this study. None of the GDM patients received any treatment before the test. The study protocol was approved by the Research Ethics Board of the International Peace Maternity and Child Health Hospital, and all participants provided their written informed consent.

\section{Plasma samples}

After an overnight fast, venous plasma samples were collected to determine fasting glucose levels and were collected again 1 and $2 \mathrm{~h}$ after oral ingestion of $75 \mathrm{~g}$ glucose. Plasma glucose was estimated by the glucose hexokinase method. The level of CG (Anogen, Mississauga, Ontario, Canada) and monocyte chemotactic protein 1 (MCP1) (R\&D Systems, Minneapolis, MN, USA) was measured by ELISA assays according to the manufacturer's protocol.

\section{Material}

3-Isobutyl-1-methylxanthine (IBMX), dexamethasone, H89, SP600125, PD98059 and BMS345541 were obtained from Sigma. CG was purchased from Calbiochem (Darmstadt, Germany) and insulin from Eli Lilly.

\section{Cell culture}

3T3-L1 cells were grown in DMEM supplemented with $10 \%$ foetal bovine serum (FBS) at $37^{\circ} \mathrm{C}$ in a humidified atmosphere of $5 \% \mathrm{CO}_{2}$. Two days after the cells reached confluence, the medium was supplemented for 2 days with $0.5 \mathrm{mmol} / \mathrm{l}$ IBMX, $1.7 \mu \mathrm{mol} / \mathrm{l}$ insulin and $1 \mu \mathrm{mol} / \mathrm{l}$ dexamethasone for adipocyte differentiation. From day 3 on, the cells were maintained with DMEM, 10\% serum and $1.7 \mu \mathrm{mol} / \mathrm{l}$ insulin. The medium was renewed every 2 days until the end of the experiment. C2C12 cells, a mouse myoblast cell line, were cultured in DMEM with 10\% FBS at $37{ }^{\circ} \mathrm{C}$ in a humidified atmosphere of $5 \% \mathrm{CO}_{2}$. When the cells approached $80-90 \%$ confluence, the growth medium was replaced with a differentiation medium consisting of DMEM supplemented with $2 \%$ horse serum to initiate differentiation. The medium was changed every other day until the cells were differentiated. After $1 \mathrm{~h}$ pretreatment with the protein kinase A (PKA) inhibitor H89 $(20 \mu \mathrm{mol} / \mathrm{l})$, MEK inhibitor PD98059 (25 $\mathrm{mol} / \mathrm{l})$, c-Jun N-terminal kinases (JNK) inhibitor SP600125 $(20 \mu \mathrm{mol} / \mathrm{l})$ or I $\kappa$ B kinase (IKK) inhibitor BMS345541 $(10 \mu \mathrm{mol} / \mathrm{l}), 3 \mathrm{~T} 3-\mathrm{L} 1$ adipocytes were treated with $5000 \mathrm{mIU} / \mathrm{ml} \mathrm{CG}$ for $24 \mathrm{~h}$.

Published by Bioscientifica Ltd. 


\section{Western blotting analysis}

3T3-L1 cells were harvested and lysed in RIPA buffer containing proteinase and phosphatase inhibitors. RIPA buffer is composed of $1 \times$ PBS, 1\% NP40, 0.1\% SDS, $5 \mathrm{mM}$ EDTA and $0.5 \%$ sodium deoxyccholate. After the protein concentration was measured by the Bradford assay, protein samples were separated on a $10 \%$ polyacrylamide gel and transferred onto a nitrocellulose membrane. The membranes were blocked using $2 \%(\mathrm{w} / \mathrm{v})$ BSA and incubated overnight at $4{ }^{\circ} \mathrm{C}$ with anti-GLUT4, antiMCP1, anti-IKKB and anti-tubulin antibodies (CST, Danvers, MA, USA), or anti-CG/LHR, anti-P65 and antiLamin B antibodies (Santa Cruz). The membranes were then incubated for at least $1 \mathrm{~h}$ at room temperature with HRP-conjugated secondary antibody (Dako, DK-2600, Glostrup, Denmark). The signal was detected using enhanced chemiluminescence (PerkinElmer, Waltham, MA, USA). Densitometry was conducted directly on the blotted membrane using a CCD camera system (LAS-4000, Fujifilm, Tokyo, Japan).

\section{RT-PCR and real-time PCR}

Total RNA was isolated using TRIzol reagent (Invitrogen) according to the manufacturer's instructions. Samples $(1 \mu \mathrm{g})$ of RNA were reverse transcribed to cDNA using anchored oligonucleotide (dT)15 primers and Superscript II Reverse Transcriptase (Invitrogen). The resulting cDNA was used as a template for PCR amplification. PCR was performed to measure the expression of $L h r$ ( $L h c g r$, ID: 16867), using a specific forward primer: 5'-AGACACTCCAATGTACTCCAG-3' and reverse primer: 5'-AACAGCATAGGTGATGGTG-3'. Gapdh (Gapdh, ID: 14433) was amplified as a control using forward primer: 5'-TTCACCACCATGGAGAAGGC-3' and reverse primer: 5'-CACACCCATCACAAACATGGG-3'. Following amplification, PCR products were electrophoresed on a $1.5 \%$ agarose gel containing ethidium bromide. Real-time PCR was performed with an ABI Prism 7300 instrument (Applied
Biosystems) in 96-well plates using the SYBR Premix Ex Taq Kit (Takara, Otsu, Shiga, Japan) according to the manufacturer's instructions. Gene expression was analysed by relative quantification with the $2^{-\triangle \Delta \mathrm{Ct}}$ method. Quantification was performed in quadruplicate, and the experiments were repeated independently three times. The sequences of the primers are listed in Table 1 . The levels of target genes were normalised to beta actin (Actb, ID: 11461), and the results are expressed as fold changes of the threshold cycle $(\mathrm{Ct})$ values relative to the controls. All of the primer sets were designed to span at least one intron to avoid amplification of genomic DNA.

\section{Transfections and luciferase assays}

The nuclear factor $\kappa$-light-chain-enhancer of activated B cells $(\mathrm{NF}-\kappa \mathrm{B})$ reporter plasmid was constructed using a pGL3 reporter plasmid (Promega) and an NF- $\kappa \mathrm{B}$ consensus sequence (5'-GGGACTTTCC-3'). Transient transfections were performed using Lipofectamine 2000 (Invitrogen) according to the manufacturer's protocol. Briefly, HEK293 cells were seeded into 24 -well plates and transfected with 900 ng pcDNA 3.1 human LHR plasmid, 300 ng NF- $\kappa$ B luciferase reporter and $3 \mathrm{ng}$ SV40 (Promega) at 40-50\% confluence. After $24 \mathrm{~h}$, the cells were treated with CG or vehicle for an additional $24 \mathrm{~h}$. The cells were then collected, and luciferase assays were conducted using a Dual-Luciferase Reporter Assay System (Promega) following the manufacturer's instructions. Data are reported as the mean value of at least three independent experiments.

\section{2-Deoxyglucose uptake assay}

Glucose transport was determined by measuring uptake of $\left[{ }^{3} \mathrm{H}\right] 2$-deoxyglucose (DOG) (PerkinElmer). 3T3-L1 cells were cultured in 24-well plates until over $90 \%$ of cells displayed an adipocyte phenotype. The cells were then treated with CG or vehicle for $24 \mathrm{~h}$. The transport assay was initiated by washing the cells twice with transport solution (Krebs Ringer's phosphate buffer). The cells were

Table 1 Primer pairs used for quantitative-PCR

\begin{tabular}{l} 
Primers \\
\hline Glut4 (SIc2a4, ID: 20528) \\
Akt (Akt1, ID: 11651) \\
II6 (II6, ID: 16193) \\
Mcp1 (CcI2, ID: 20296) \\
PAI1 (Serpine1, ID: 18787) \\
Adipoq (Adipoq, ID: 11450) \\
B actin (Actb, ID: 11461)
\end{tabular}

\section{Sense}

GCCCCACAGAAGGTGATTG GAACGACGTAGCCATTGTGAAG TCTCTGGGAAATCGTGGAAATG AGGTCCCTGTCATGCTTCTGG CACAGTGGCGTCTTCCTCCA GATGGCAGAGATGGCACTCC GACTTCGAGCAGGAGATGGC

\begin{tabular}{l} 
Antisense \\
\hline AGCGTAGTGAGGGTGCCTTG \\
ATCCTGAGGCCGTTCCTTG \\
TCCAGTTTGGTAGCATCCATCA \\
GGTGAATGAGTAGCAGCAGGTG \\
TGTCTCTGTCGGGTTGTGCC \\
CTTGCCAGTGCTGCCGTCAT \\
CCCAAGAAGGAAGGCTGGA
\end{tabular}


then incubated in the transport solution for another $15 \mathrm{~min}$ in the presence or absence of $100 \mathrm{nM}$ insulin at $37^{\circ} \mathrm{C}$, followed by $0.5 \mu \mathrm{Ci}\left[{ }^{3} \mathrm{H}\right] 2$-DOG for $30 \mathrm{~min}$. After incubation, the cells were quickly washed three times with ice-cold PBS containing $10 \mathrm{mM}$ glucose. They were then lysed in $0.1 \mathrm{~mol} / 1 \mathrm{NaOH}$ and subsequently solubilised in scintillation fluid overnight. $\left[{ }^{3} \mathrm{H}\right] 2-\mathrm{DOG}$ was measured using a liquid scintillation counter.

\section{Statistical analyses}

All data are expressed as the mean \pm s.D. Student's $t$-test or ANOVA analysis followed by Bonferroni's post-test was used for comparison between groups, as appropriate. Stepwise multiple linear regression analysis was performed to assess the associations between CG concentrations and glucose levels. Statistical analysis was performed using a SAS system (version 9.3; SAS Institute, Inc., Cary, NC, USA). Differences with $P<0.05$ were considered to be statistically significant.

\section{Results}

\section{CG/LH receptors are expressed at low levels} in insulin-sensitive mouse cells

In a previous study, the CG/LHR was detected in human adipose tissue (Dos Santos et al. 2007). In our study, we first analysed the expression of the CG/LHR in insulinsensitive cells (3T3-L1 adipocytes and C2C12 myoblasts) by RT-PCR. As shown in Fig. 1A, the $L h r$ gene was expressed at a low level in 3T3-L1 adipocytes and C2C12 myoblasts. Western blotting analysis further demon-

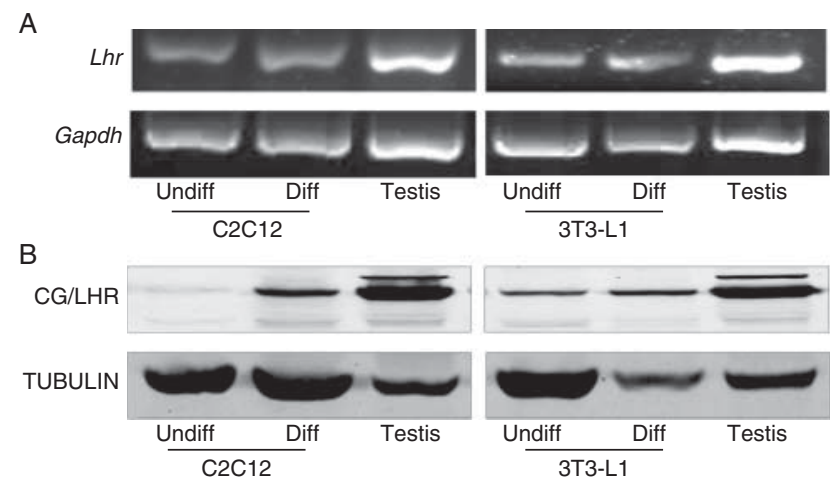

Figure 1

CG/LHR is expressed in insulin-sensitive cells. (A) Lhr expression in 3T3-L1 and $\mathrm{C} 2 \mathrm{C} 12$ cells was measured by RT-PCR; testis was used as a positive control. (B) CG/LHR expression in 3T3-L1 and C2C12 cells was measured by western blot analysis. Testis was used as a positive control. strated the expression of CG/LHR protein in these cells. In mouse adipocytes and myoblasts, the molecular mass of CG/LHR was approximately $80-90 \mathrm{kDa}$, which was the same as observed in the testis. Moreover, mature 3T3-L1 adipocytes and C2C12 myoblasts expressed more CG/LHR protein than undifferentiated precursor cells (Fig. 1B).

\section{CG suppresses insulin-responsive gene expression in 3T3-L1 adipocytes and further influences insulin-stimulated glucose uptake}

The expression of the CG/LHR in the insulin-sensitive cells indicated that CG may affect insulin sensitivity. We then observed the effect of CG on mature adipocytes. By quantitative PCR, we found that the gene expression of adiponectin (Adipoq, ID: 11450), glucose transporter 4 (Glut4, Slc2a4, ID: 20528) and protein kinase B (Akt, Akt1, ID: 11651) was reduced by CG. After $6 \mathrm{~h}$ CG incubation, expression of Adipoq decreased to approximately $80 \%$ of control levels with $5000 \mathrm{mIU} / \mathrm{ml} \mathrm{CG}$ treatment, while expression of $A k t$ decreased to $88 \%$ with $500 \mathrm{mIU} / \mathrm{ml}$ and $53 \%$ with $5000 \mathrm{mIU} / \mathrm{ml} \mathrm{CG}$ treatment in 3T3-L1 cells. Notably, expression of Glut4 mRNA decreased to $72 \%$ of control levels with $500 \mathrm{mIU} / \mathrm{ml}$ and $40 \%$ with $5000 \mathrm{mIU} / \mathrm{ml} \mathrm{CG}$ treatment (Fig. 2A). Moreover, inhibition of Akt and Glut4 sustained for $24 \mathrm{~h}$ (Fig. 2B). As expression of Glut4 was inhibited more significantly, we further investigated GLUT4 protein expression after incubation with different doses of CG for $24 \mathrm{~h}$. Results of western blotting analysis indicated that GLUT4 protein expression was suppressed by the higher doses of CG (Fig. 2C). GLUT4 is an insulin-regulated glucose transporter found in adipose and muscle tissue (James et al. 1988, Watson et al. 2004). We thus evaluated insulin-stimulated glucose uptake by 3T3-L1 adipocytes. The results of the 2-DOG uptake assay indicated that insulin treatment stimulated a sevenfold increase in glucose uptake compared with PBS treatment; however, after pretreating with CG for $24 \mathrm{~h}$, insulin increased glucose uptake by merely 5.7-fold, a decrease by approximately $20 \%$ compared with the control group (Fig. 2D). Taken together, these results indicated that CG attenuates insulin sensitivity in adipocytes in part by influencing insulin-responsive genes and impairing insulin-stimulated glucose uptake.

\section{CG modulates proinflammatory cytokines in 3T3-L1 adipocytes}

To our knowledge, chronic inflammation contributes to IR in pregnancy. Though CG attenuates the insulin

Published by Bioscientifica Ltd 
A
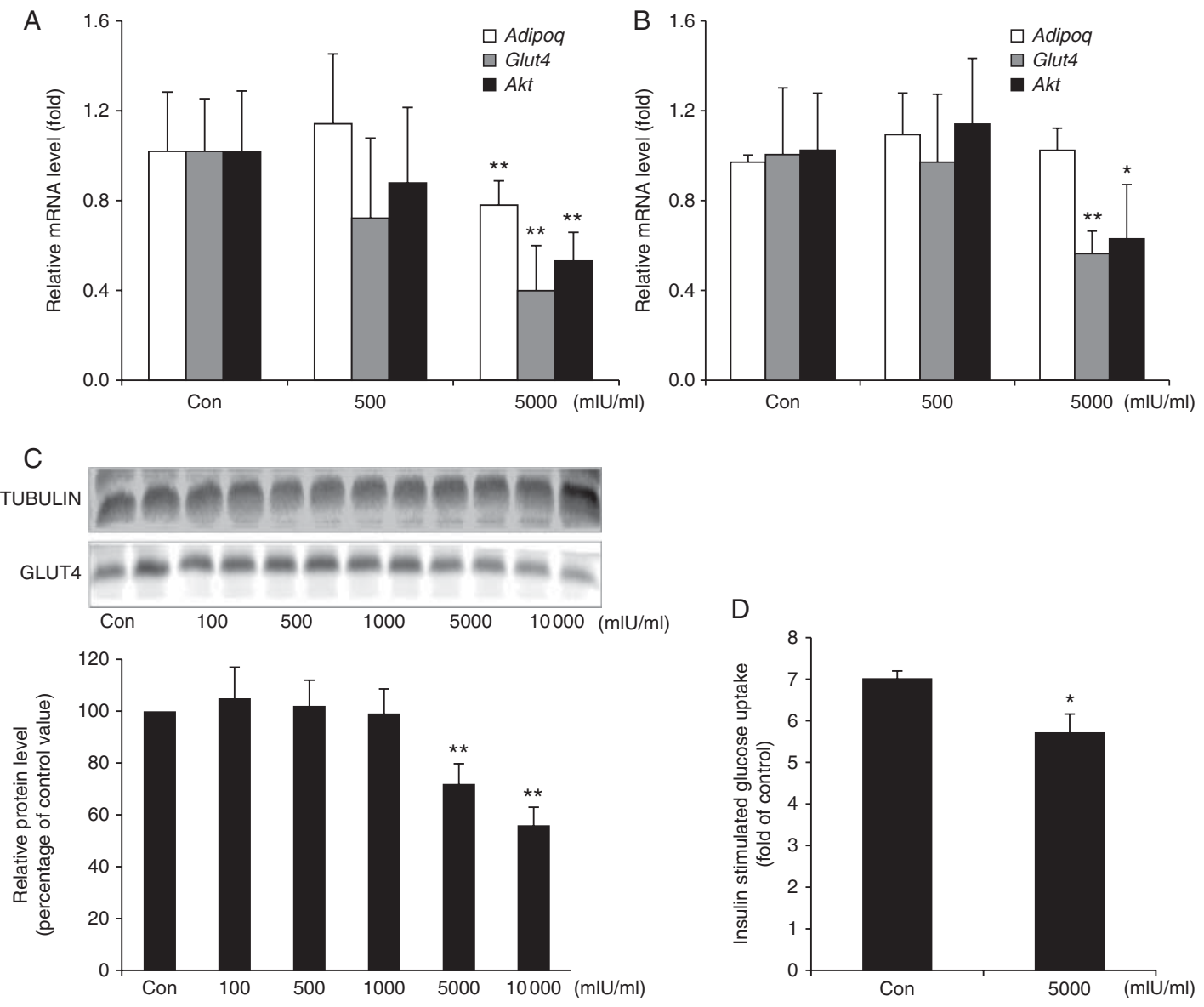

Figure 2

CG decreases the expression of insulin-responsive genes while inhibiting insulin-stimulated glucose uptake in 3T3-L1 adipocytes. (A and B) Gene expression of Adipoq, Glut4 and Akt was measured by quantitative PCR in mature 3T3-L1 adipocytes after treatment with 500 or $5000 \mathrm{mIU} / \mathrm{ml}$ CG for $6 \mathrm{~h}(\mathrm{~A})$ and $24 \mathrm{~h}(\mathrm{~B}),{ }^{*} P<0.05 ;{ }^{*} P<0.01$. Relative mRNA levels were normalised to $\beta$ actin and compared with the untreated control. Data are represented as means \pm s.D. of three independent experiments. (C) GLUT4 protein expression is downregulated by CG in a dose-dependent manner on the basis of western blot. Glut4 expression was normalised to TUBULIN.

response in 3T3-L1 adipocytes, its effects on adipocyte inflammation remain unknown. To evaluate adipocyte inflammation, we quantified proinflammatory cytokine expression in 3T3-L1 adipocytes following 6 or $24 \mathrm{~h}$ of CG treatment. As shown in Fig. 3, expression of plasminogen activator inhibitor 1 (Pai1, Serpine1, ID: 18787) and interleukin 6 (Il6, ID: 16193) was not altered after CG treatment. However, Mcp1 (Ccl2, ID: 20296) was induced by 500 and $5000 \mathrm{mIU} / \mathrm{ml}$ of CG, increasing by approximately 20\% compared with control levels after $6 \mathrm{~h}$ (Fig. 3A) and $60 \%$ after $24 \mathrm{~h}$ (Fig. 3B) of treatment. We further investigated the effects of a $24-\mathrm{h}$ CG treatment on MCP1 protein expression and found that CG treatment upregulated MCP1 protein levels, even at a lower dose
Bands were quantified by densitometry using the Quantity One system. The protein levels were expressed as percentages relative to the control value. Data are represented as means \pm s.D. of three independent experiments, $* P<0.05, * * P<0.01$, compared with control. (D) CG attenuates insulin-stimulated glucose uptake. Glucose transport in 3T3-L1 adipocytes was determined by measuring the uptake of $\left[{ }^{3} \mathrm{H}\right] 2-\mathrm{DOG}$. Insulin-stimulated glucose uptake was expressed as fold change compared with non-insulin-stimulated controls.

(Fig. 3C). Our present results indicated that CG primarily stimulates adipocytes to produce MCP1, which further recruits macrophages to exacerbate inflammation.

\section{CG in 3T3-L1 adipocytes functions partly by activating the IKKB/NF-KB signalling pathway}

The classical CG signal transduction pathway involves activation of the adenylate cyclise cAMP protein kinase A (AC cAMP PKA) pathway (Segaloff \& Ascoli 1993). In addition, it has been reported that the mitogen activated protein kinase (MAPK) pathway may be an important signalling pathway in non-gonadal sites expressing CG/LHR (Rao 2001). To investigate these signalling

Published by Bioscientifica Ltd. 

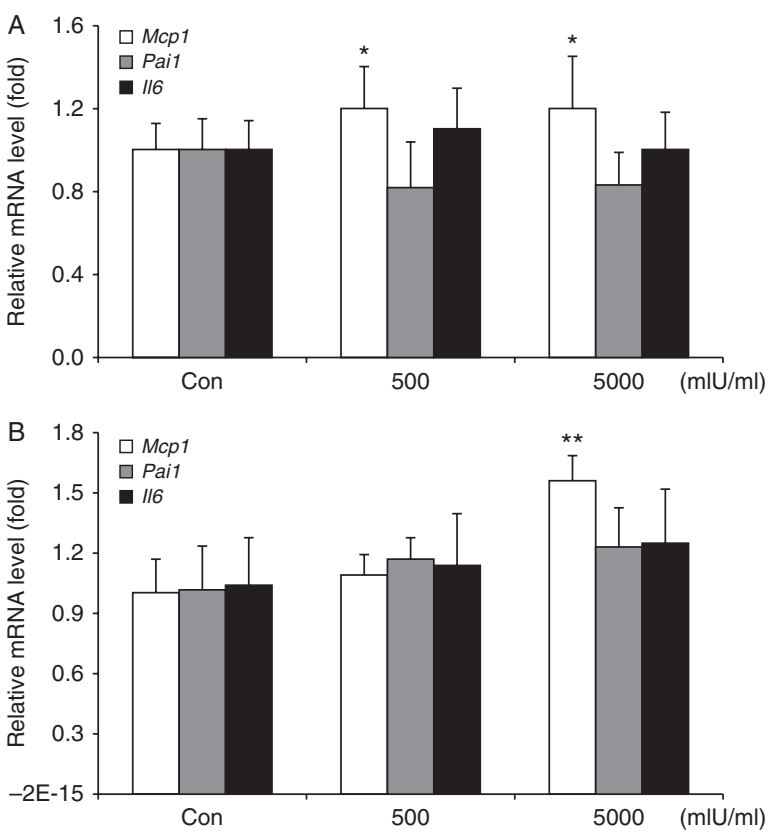

C
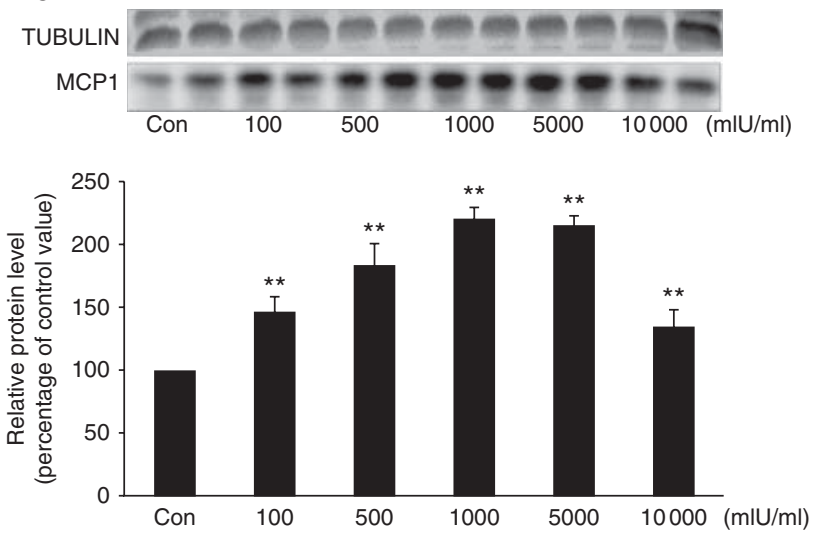

Figure 3

CG modulates pro-inflammatory cytokines in 3T3-L1 adipocytes. (A and B) Gene expression of Mcp1, Pai1 and II6 in mature 3T3-L1 adipocytes was measured by quantitative PCR after incubation with 500 or $5000 \mathrm{mIU} / \mathrm{ml} \mathrm{CG}$ for $6 \mathrm{~h}(\mathrm{~A})$ and $24 \mathrm{~h}(\mathrm{~B}),{ }^{*} P<0.05 ;{ }^{*} P<0.01$. Relative mRNA levels were normalised to $\beta$ actin and compared with those for the untreated control. Data are presented as means \pm s.D. of three independent experiments. (C) MCP1 protein expression was stimulated by CG in a dose-dependent manner. After incubation with $100 \mathrm{mIU} / \mathrm{ml}$ and $10000 \mathrm{mlU} / \mathrm{ml} \mathrm{CG}, \mathrm{MCP} 1$ protein levels were evaluated by western blotting. MCP1 expression was normalised to tubulin. Bands were quantified by densitometry using the Quantity One system. Protein levels are expressed as percentages relative to the control value. Data are presented as means \pm s.D. of three independent experiments, $* P<0.05, * * P<0.01$, compared with control.

pathways in adipocytes, 3T3-L1 cells were pretreated with the PKA inhibitor H89 or the mitogen-activated protein kinase kinase (MEK) inhibitor PD98059 before $24 \mathrm{~h}$ of treatment with $5000 \mathrm{mIU} / \mathrm{ml} \mathrm{CG}$. Results of western blot analysis indicated that preincubation with H89 blocked the CG-induced decrease in GLUT4 expression, whereas the increase in MCP1 was not influenced (Fig. 4A). These results indicated that the AC cAMP PKA pathway partially mediates the CG-induced inhibition of GLUT4. In addition, we tested whether the inflammatory NF-kB or c-Jun $\mathrm{N}$-terminal kinase (JNK) signalling pathways mediated the effect of CG on 3T3-L1 cells. Interestingly, as shown in Fig. 4A, pretreatment with the IкB kinase (IKK) inhibitor BMS345541 blocked CG-induced suppression of GLUT4 protein but did not block upregulation of MCP1, which indicated that NF- $\kappa \mathrm{B}$ signalling is a potential mechanism for CG activity in 3T3-L1 cells. Activation of NF- $\kappa$ B signalling by CG was further tested by luciferase assays. When HEK293 cells were contransfected with an NF- $\kappa B$ luciferase reporter and pcDNA 3.1 CG/LH receptor, the activity of NF- $\kappa \mathrm{B}$ was upregulated by CG in a dose-dependent manner (Fig. 4B); however, when transfected with the NF-кB luciferase reporter alone, CG could not activate NF- $\mathrm{KB}$ signalling (results not shown). Moreover, we observed that IKKB phosphorylation in 3T3-L1 adipocytes was directly promoted by $60 \mathrm{~min}$ of $5000 \mathrm{mIU} / \mathrm{ml} \mathrm{CG}$ treatment (Fig. 4C). P65 nuclear translocation was also increased after $2 \mathrm{~h}$ of CG treatment (Fig. 4D). In summary, these results strongly indicate that, apart from the AC cAMP PKA pathway and MAPK pathway, NF-KB signalling is an important pathway for the function of CG in 3T3-L1 adipocytes.

\section{Elevated CG levels in pregnant women with GDM are associated with abnormal glucose tolerance}

A total of 89 pregnant women were included in our final study: 42 patients were GDM and 47 patients had NGT. As listed in Table 2, glucose levels, including fasting and 1- and 2-h post glucose load, were higher in GDM. However, there was no significant difference in the age of the two groups $(28.85 \pm 2.37$ versus $29.25 \pm 2.26)$. No significant association was found between age and fasting, 1- and 2-h glucose levels. Moreover, prepregnancy BMI in GDM subjects was higher than that of NGT subjects $(25.83 \pm 2.7$ versus $23.85 \pm 2.62)$, and prepregnancy BMI was associated with fasting $(P<0.0001)$ and 1-h $(P=0.002)$ glucose levels (Table 3). Results of ELISA assays also indicated that MCP1, a key factor in the recruitment and activation of peripheral blood leukocytes, was elevated in GDM woman compared with healthy pregnant women $(83.71 \pm 21.1$ versus $100.72 \pm 32.82 \mathrm{pg} / \mathrm{ml}$ ), which was consistent with previous report (Klein et al. 2008). Furthermore, MCP1 levels were associated with abnormal 1- $(P=0.025)$ and 2-h $(P=0.008)$ post glucose load (Table 3$)$. Interestingly, the elevated CG levels in pregnancy were notably higher in

Published by Bioscientifica Ltd. 
A
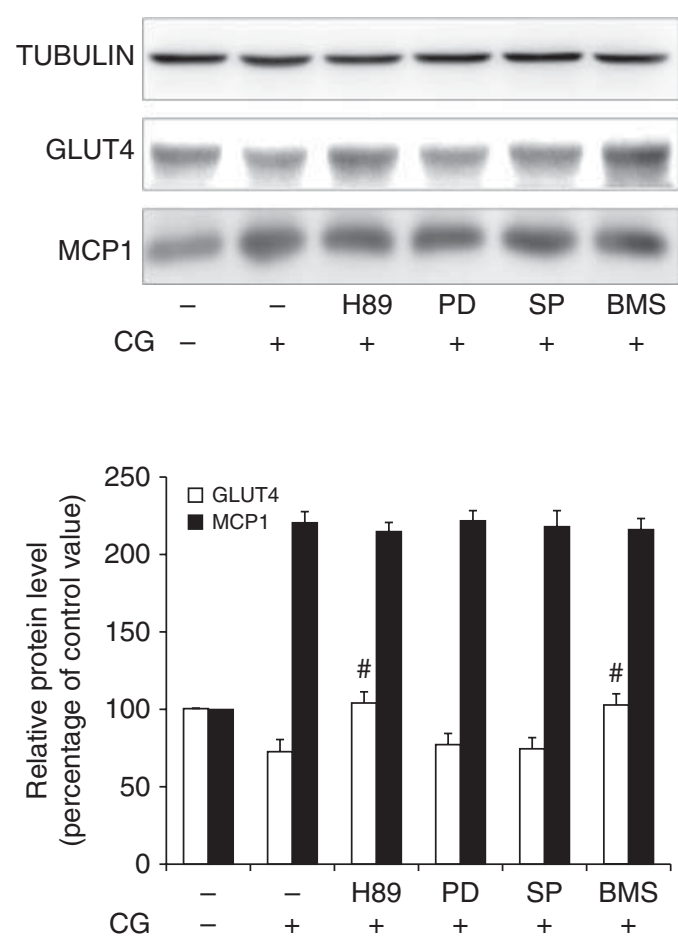

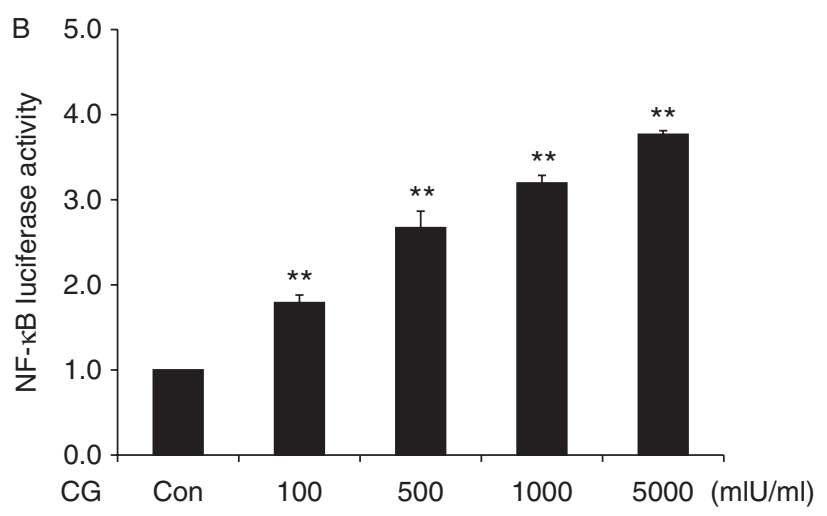

C

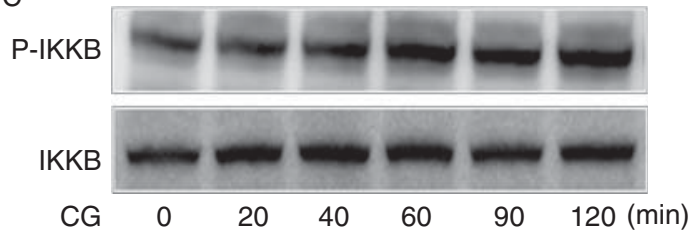

D

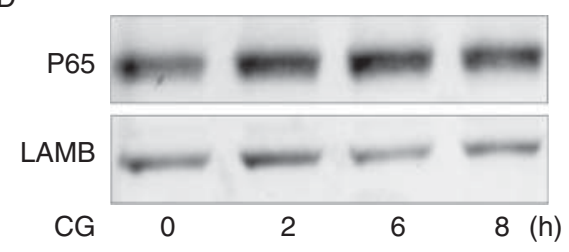

Figure 4

CG activates the IKKB/NF-KB signalling pathway in 3T3-L1 adipocytes. (A) CG decreases GLUT4 protein levels partially via the AC CAMP PKA and IKKB/NF-KB signalling pathways. After $1 \mathrm{~h}$ pretreatment with the PKA inhibitor H89 $(20 \mu \mathrm{mol} / \mathrm{l})$, MEK inhibitor PD98059 $(25 \mu \mathrm{mol} / \mathrm{l})$, JNK inhibitor SP600125 $(20 \mu \mathrm{mol} / \mathrm{l})$ or IKK inhibitor BMS345541 $(10 \mu \mathrm{mol} / \mathrm{l})$, 3T3-L1 adipocytes were treated with $5000 \mathrm{mIU} / \mathrm{ml} \mathrm{CG}$ for $24 \mathrm{~h}$. MCP1 and GLUT4 protein levels were then analysed by western blot. (B) CG activates the IKKB/NF-KB signalling pathway as tested by luciferase assays. After cotransfection of an NF-KB luciferase reporter and pcDNA 3.1 CG/LH receptor into HEK293 cells, the cells were treated with CG or vehicle for $24 \mathrm{~h}$. The cells were then collected for luciferase assays using a Dual-Luciferase Reporter Assay System. (C) CG phosphorylates IKKB in a

the GDM than in the NGT group (144 668.8 \pm 76761.9 versus $63999.04 \pm 54871.3 \mathrm{mIU} / \mathrm{ml})$, in particular, CG levels were associated with abnormal 1-h post glucose load $(P=0.006)$ (Table 3). These clinical data further supported the hypothesis that higher CG may contribute to inflammation and IR in GDM.

\section{Discussion}

CG is indispensable for maintenance of human pregnancy as well as gametogenesis and production of gonadal sex steroids (Pierce \& Parsons 1981, Cole 2010). Results described in recent publications have indicated that time-dependent manner in 3T3-L1 adipocytes. 3T3-L1 adipocytes were incubated with $5000 \mathrm{mIU} / \mathrm{ml} \mathrm{CG}$ for the indicated time periods, and phosphorylated IKKB was detected by western blotting and compared with total IKKB. (D) CG enhances P65 nuclear localisation in a time-dependent manner in 3T3-L1 adipocytes. 3T3-L1 adipocytes were incubated with $5000 \mathrm{mIU} / \mathrm{ml} \mathrm{CG}$ for the indicated time periods, and the amount of nuclear P65 was detected by western blotting. P65 expression was compared with that of lamin B (LAMB). Bands were quantified by densitometry using the Quantity One system. Protein levels are expressed as the fold change relative to control. Data are presented as means \pm s.D. of three independent experiments, ${ }^{*} P<0.05,{ }^{*} P<0.01$, compared with control, ${ }^{\#} P<0.05$, compared with CG treatment.

CG/LHR is expressed in a variety of extragonadal tissues and that CG has extragonadal functions (Rao 2001, Abdallah et al. 2004). In particular, CG may either stimulate (Czerwiec et al. 1989, Horiuchi et al. 2000) or inhibit (Ku et al. 2002, Rao et al. 2004) the growth of different cell types. CG has also been characterised as a novel angiogenic factor in human endothelial cells (Zygmunt et al. 2002). Dos Santos et al. (2007) reported that CG/LHR is expressed in human primary adipocytes and that the proadipogenic effect of CG in human preadipocytes leads to the increased fat storage that occurs during the first trimester of pregnancy. In this study, we first confirmed that mature 3T3-L1 adipocytes and C2C12

Published by Bioscientifica Ltd. 
Table 2 Clinical parameters of NGT and GDM

\begin{tabular}{l}
\hline Age (years) \\
Prepregnancy BMI $\left(\mathrm{kg} / \mathrm{m}^{2}\right)$ \\
Fasting glucose $(\mathrm{mmol} / \mathrm{l})$ \\
$1 \mathrm{~h}$ glucose $(\mathrm{mmol} / \mathrm{l})$ \\
$2 \mathrm{~h}$ glucose $(\mathrm{mmol} / \mathrm{l})$ \\
CG $(\mathrm{mlU} / \mathrm{ml})$ \\
MCP1 $(\mathrm{pg} / \mathrm{ml})$
\end{tabular}

\begin{tabular}{c} 
NGT \\
\hline $28.85 \pm 2.37$ \\
$23.85 \pm 2.62$ \\
$4.15 \pm 0.33$ \\
$7.08 \pm 1.36$ \\
$6.30 \pm 1.01$ \\
$63999.04 \pm 54871.3$ \\
$83.71 \pm 21.1$ \\
\hline
\end{tabular}

cells express CG/LHR, which indicates a functional role for CG in these insulin-sensitive cells. Furthermore, we observed that the expression of insulin-responsive genes, including $A D I P O Q, A K T$ and GLUT4, was suppressed by CG treatment of mature 3T3-L1 cells. ADIPOQ, an important adipokine, is specifically enriched in adipose tissue and directly sensitises the body to insulin (Kadowaki et al. 2006). In GDM pregnancies, ADIPOQ levels decrease independently from maternal BMI or insulin sensitivity (Kinalski et al. 2005, Ategbo et al. 2006). Our results indicate that higher levels of CG might be an important reason for the decreased ADIPOQ in patients with GDM. Moreover, previous results confirm that decreased expression of GLUT4, an insulin-regulated glucose transporter, results in impaired insulin-stimulated glucose transport (James et al. 1988, Watson et al. 2004). In our study, CG decreased GLUT4 levels so as to influence insulin-stimulated glucose uptake in 3T3-L1 adipocytes. In addition, AKT, a modulator of insulin signalling that is important for the maintenance of normal glucose homeostasis (Cho et al. 2001) was also downregulated by CG. Taking these results together, higher level of CG decreased the expression of insulin-responsive genes and reduced insulin-stimulated glucose uptake in 3T3-L1 adipocytes, which indicated that CG may impair insulin sensitivity in vivo to induce the development of GDM, in view of higher CG in pregnancy and GDM.

Inflammation in pregnancy is correlated with IR in GDM (Wolf et al. 2004, Korkmazer \& Solak 2014). As

\begin{tabular}{ccc}
\hline GDM & & P value \\
\cline { 1 - 1 } $29.25 \pm 2.26$ & & 0.442337 \\
$25.83 \pm 2.7$ & & 0.001152 \\
$4.5 \pm 0.47$ & $<0.001$ \\
$10.4 \pm 1.16$ & $<0.001$ \\
$8.82 \pm 1.32$ & $<0.001$ \\
$144668.8 \pm 76761.9$ & & 0.001 \\
$100.72 \pm 32.82$ & & 0.007265
\end{tabular}

inflammatory cytokines, such as TNF- $\alpha$ (Hotamisligil et al. 1993), IL6 (Rotter et al. 2003) and PAI1 (Shimomura et al. 1996) and chemokines such as MCP1 (Sartipy \& Loskutoff 2003, Kanda et al. 2006) are expressed in adipose tissue, we further assessed changes in cytokine expression after incubation 3T3-L1 adipocytes with CG. Among the cytokines we tested, MCP1 was significantly upregulated by CG. MCP1 is predominantly produced by macrophages and endothelial cells and is a potent chemotactic factor for monocytes (Takahashi et al. 2003). Increased MCP1 contributes to macrophage infiltration and IR (Sartipy \& Loskutoff 2003, Kanda et al. 2006). Clinically, results from previous studies have also indicated that MCP1 is elevated during pregnancy and further augmented in GDM compared with NTG. Consistent with the results reported by Klein et al. (2008), our clinical detection of MCP1 also found elevated MCP1 concentration in GDM women; moreover, elevated MCP1 is associated with abnormal glucose tolerance. Although it has been proposed that this inflammation is mediated by the placenta (Klein et al. 2008), our results confirmed that elevated MCP1 levels in pregnancy were produced by increased fat mass under surged CG stimulation.

After binding to CG/LHR, CG activated multiple signal transduction effector systems, including, importantly, the AC cAMP PKA and MAPK pathways (Cole 2010). We found that the AC cAMP PKA pathway partially mediated CG-induced GLUT4 suppression. Interestingly, CG can activate NF- $\kappa \mathrm{B}$ in adipocytes. NF- $\kappa \mathrm{B}$ is a

Table 3 The association of the glucose concentrations with age, prepregnancy BMI, MCP1 and CG level

\begin{tabular}{|c|c|c|c|c|c|c|c|c|c|}
\hline & \multicolumn{3}{|c|}{ Glucose fasting (mmol/l) } & \multicolumn{3}{|c|}{ Glucose $1 \mathrm{~h}(\mathrm{mmol} / \mathrm{l})$} & \multicolumn{3}{|c|}{ Glucose $2 \mathrm{~h}(\mathrm{mmol} / \mathrm{l})$} \\
\hline & $\beta \pm$ S.E.M. & Standard $P$ & $P$ & $\beta \pm$ S.E.M. & Standard $P$ & $P$ & $\beta \pm$ S.E.M. & Standard $P$ & $P$ \\
\hline Age & - & - & - & - & - & - & - & - & - \\
\hline $\begin{array}{l}\text { Prepregnancy } \\
\text { BMI }\left(\mathrm{kg} / \mathrm{m}^{2}\right)\end{array}$ & $0.074 \pm 0.015$ & 0.477 & $<0.0001$ & $0.249 \pm 0.077$ & 0.335 & 0.0019 & - & - & - \\
\hline MCP1 (pg/ml) & - & - & - & $0.015 \pm 0.007$ & 0.208 & 0.0253 & $0.017 \pm 0.006$ & 0.282 & 0.008 \\
\hline CG (mlU/ml) & - & - & - & $0.711 \pm 0.254$ & 0.257 & 0.0064 & - & - & - \\
\hline $\begin{array}{l}\text { Fasting glucose } \\
\text { (mmol/l) }\end{array}$ & - & - & - & $1.242 \pm 0.499$ & 0.259 & 0.0149 & $1.145 \pm 0.409$ & 0.29 & 0.007 \\
\hline $\begin{array}{l}\text { http://jme.endocrino } \\
\text { DOI: } 10.1530 / J M E-14\end{array}$ & $\begin{array}{l}\text { y-journals.org } \\
84\end{array}$ & (ㄷ) 2015 & $\begin{array}{l}\text { ciety for Endo } \\
\text { Printed in Gre }\end{array}$ & $\begin{array}{l}\text { inology } \\
\text { t Britain }\end{array}$ & Di & a Ltd. & & & \\
\hline
\end{tabular}


transcription factor that plays a key role in inflammatory and immune responses. The IKKB/NF- $\kappa \mathrm{B}$ signalling pathway is activated by inflammatory stressors and regulates the expression of cytokines and growth factors that regulate inflammatory pathways (Karin \& Delhase 2000). NF- $\kappa$ B has been implicated in obesity-induced IR and deranged glucose metabolism by both pharmacological and genetic approaches (Yuan et al. 2001). CG activation of NF- $\mathrm{KB}$ signalling further confirmed that CG plays a role in inflammation and IR.

In addition, using stepwise multiple linear regression analysis, we found that prepregnancy BMI is associated with disturbed glucose tolerance, which is consistent with results described in previous reports (Gomez-Ambrosi et al. 2011, Arjmandi Far et al. 2012). More importantly, apart from prepregnancy BMI and MCP1 levels, CG level is associated with elevated 1-h post glucose load of pregnant women. The analysis of clinical data strongly supported the hypothesis that CG attenuates insulin sensitivity and contributes to disturbed glucose tolerance.

Although persistent CG stimulation of Leydig cells has been reported to induce oxidative stress (Aggarwal et al. 2009), which is a contributor to IR (Furukawa et al. 2004), the expression of oxidative-stress-related genes was not influenced by CG in adipocytes (data not shown). In our study, we found that CG/LHR was also expressed in C2C12 cells, another important type of insulin-responsive cells, which indicated that CG possibly plays a role in these cells, this will be clarified in the future.

In conclusion, through CG/LHR in adipocytes, the higher CG in GDM directly impairs insulin sensitivity and induces inflammation to exacerbate IR, which contributes to GDM development to some extent.

\section{Declaration of interest}

The authors declare that there is no conflict of interest that could be perceived as prejudicing the impartiality of the research reported.

\section{Funding}

This work was supported by grants from the National Natural Science Foundation of China (No. 81270867) and Shanghai Municipal Health Bureau Funding (No. 2011-94)

\section{Author contribution statement}

$\mathrm{G} N$ and $\mathrm{Q} M$ designed the studies. $\mathrm{Q} \mathrm{M}, \mathrm{J} \mathrm{W}$ and $\mathrm{Q} \mathrm{L}$ performed all the experimental procedures and experimental data analyses. J F, S Y and Q C collected and analysed all the clinical data. Q M and R L wrote the manuscript. All authors contributed to the discussion and revised the manuscript and all approved the final version. $\mathrm{G} \mathrm{N}$ is responsible for the integrity of the work as a whole.

\section{Acknowledgements}

The authors thank Jian Chen (Institute of Health Sciences, Shanghai Institutes for Biological Sciences, Chinese Academy of Sciences) for assistance with the 2-DOG uptake assay.

\section{References}

Abdallah MA, Lei ZM, Li X, Greenwold N, Nakajima ST, Jauniaux E \& Rao Ch V 2004 Human fetal nongonadal tissues contain human chorionic gonadotropin/luteinizing hormone receptors. Journal of Clinical Endocrinology and Metabolism 89 952-956. (doi:10.1210/jc.2003-030917)

Aggarwal A, Misro MM, Maheshwari A, Sehgal N \& Nandan D 2009 Adverse effects associated with persistent stimulation of Leydig cells with hCG in vitro. Molecular Reproduction and Development 76 1076-1083. (doi:10.1002/mrd.21074)

American Diabetes Association 2011 Standards of medical care in diabetes 2011. Diabetes Care 34 (Suppl 1) S11-S61. (doi:10.2337/dc11-S011)

Androutsopoulos G, Gkogkos P, Vassilakos P, Panayiotakis G \& Decavalas G 2009 Mid-trimester maternal serum hCG levels in predicting adverse pregnancy outcome. Clinical and Experimental Obstetrics \& Gynecology 36 173-175.

Arjmandi Far M, Ziaei S \& Kazemnejad A 2012 The impact of maternal age, pre-pregnancy body mass index, weight gain and parity on glucose challenge test (GCT). International Journal of Fertility \& Sterility 5 207-210.

Ategbo JM, Grissa O, Yessoufou A, Hichami A, Dramane KL, Moutairou K, Miled A, Grissa A, Jerbi M, Tabka Z et al. 2006 Modulation of adipokines and cytokines in gestational diabetes and macrosomia. Journal of Clinical Endocrinology and Metabolism 91 4137-4143. (doi:10.1210/ jc.2006-0980)

de Castro J, Sevillano J, Marciniak J, Rodriguez R, Gonzalez-Martin C, Viana M, Eun-suk OH, de Mouzon SH, Herrera E \& Ramos MP 2011 Implication of low level inflammation in the insulin resistance of adipose tissue at late pregnancy. Endocrinology 152 4094-4105. (doi:10.1210/en.2011-0068)

Catalano PM, Roman-Drago NM, Amini SB \& Sims EA 1998 Longitudinal changes in body composition and energy balance in lean women with normal and abnormal glucose tolerance during pregnancy. American Journal of Obstetrics and Gynecology 179 156-165. (doi:10.1016/S00029378(98)70267-4)

Cho H, Mu J, Kim JK, Thorvaldsen JL, Chu Q, Crenshaw EB III, Kaestner KH, Bartolomei MS, Shulman GI \& Birnbaum MJ 2001 Insulin resistance and a diabetes mellitus-like syndrome in mice lacking the protein kinase Akt2 (PKB $\beta)$. Science 292 1728-1731. (doi:10.1126/science.292. 5522.1728)

Cole LA 2010 Biological functions of hCG and hCG-related molecules. Reproductive Biology and Endocrinology 8 102. (doi:10.1186/1477-7827-8-102)

Czerwiec FS, Melner MH \& Puett D 1989 Transiently elevated levels of c-fos and c-myc oncogene messenger ribonucleic acids in cultured murine Leydig tumor cells after addition of human chorionic gonadotropin. Molecular Endocrinology 3 105-109. (doi:10.1210/mend-3-1-105)

Dos Santos E, Dieudonne MN, Leneveu MC, Pecquery R, Serazin V \& Giudicelli Y 2007 In vitro effects of chorionic gonadotropin hormone on human adipose development. Journal of Endocrinology 194 313-325. (doi:10.1677/JOE-06-0101)

Furukawa S, Fujita T, Shimabukuro M, Iwaki M, Yamada Y, Nakajima Y, Nakayama O, Makishima M, Matsuda M \& Shimomura I 2004 Increased oxidative stress in obesity and its impact on metabolic syndrome. Journal of Clinical Investigation 114 1752-1761. (doi:10.1172/JCI21625)

Published by Bioscientifica Ltd. 
Gilmartin AB, Ural SH \& Repke JT 2008 Gestational diabetes mellitus. Reviews in Obstetrics \& Gynecology 1 129-134.

Gomez-Ambrosi J, Silva C, Galofre JC, Escalada J, Santos S, Gil MJ, Valenti V, Rotellar F, Ramirez B, Salvador J et al. 2011 Body adiposity and type 2 diabetes: increased risk with a high body fat percentage even having a normal BMI. Obesity 19 1439-1444. (doi:10.1038/oby.2011.36)

Heikkila A, Makkonen N, Heinonen S \& Kirkinen P 2001 Elevated maternal serum hCG in the second trimester increases prematurity rate and need for neonatal intensive care in primiparous preeclamptic pregnancies. Hypertension in Pregnancy 20 99-106. (doi:10.3109/ 10641950109152646)

Horiuchi A, Nikaido T, Yoshizawa T, Itoh K, Kobayashi Y, Toki T, Konishi I \& Fujii S 2000 HCG promotes proliferation of uterine leiomyomal cells more strongly than that of myometrial smooth muscle cells in vitro. Molecular Human Reproduction 6 523-528. (doi:10.1093/molehr/6.6.523)

Hotamisligil GS, Shargill NS \& Spiegelman BM 1993 Adipose expression of tumor necrosis factor- $\alpha$ : direct role in obesity-linked insulin resistance. Science 259 87-91. (doi:10.1126/science.7678183)

James DE, Brown R, Navarro J \& Pilch PF 1988 Insulin-regulatable tissues express a unique insulin-sensitive glucose transport protein. Nature $\mathbf{3 3 3}$ 183-185. (doi:10.1038/333183a0)

Kadowaki T, Yamauchi T, Kubota N, Hara K, Ueki K \& Tobe K 2006 Adiponectin and adiponectin receptors in insulin resistance, diabetes, and the metabolic syndrome. Journal of Clinical Investigation 116 1784-1792. (doi:10.1172/JCI29126)

Kanda H, Tateya S, Tamori Y, Kotani K, Hiasa K, Kitazawa R, Kitazawa S, Miyachi H, Maeda S, Egashira K et al. 2006 MCP-1 contributes to macrophage infiltration into adipose tissue, insulin resistance, and hepatic steatosis in obesity. Journal of Clinical Investigation 116 1494-1505. (doi:10.1172/JCI26498)

Karin M \& Delhase M 2000 The IкB kinase (IKK) and NF-кB: key elements of proinflammatory signalling. Seminars in Immunology 12 85-98. (doi:10.1006/smim.2000.0210)

Kinalski M, Telejko B, Kuzmicki M, Kretowski A \& Kinalska I 2005 Tumor necrosis factor $\alpha$ system and plasma adiponectin concentration in women with gestational diabetes. Hormone and Metabolic Research $\mathbf{3 7}$ 450-454. (doi:10.1055/s-2005-870238)

Kirwan JP, Hauguel-De Mouzon S, Lepercq J, Challier JC, Huston-Presley L, Friedman JE, Kalhan SC \& Catalano PM 2002 TNF- $\alpha$ is a predictor of insulin resistance in human pregnancy. Diabetes 51 2207-2213. (doi:10.2337/diabetes.51.7.2207)

Klein K, Satler M, Elhenicky M, Brix J, Krzyzanowska K, Schernthaner G, Husslein PW \& Schernthaner GH 2008 Circulating levels of MCP-1 are increased in women with gestational diabetes. Prenatal Diagnosis $\mathbf{2 8}$ 845-851. (doi:10.1002/pd.2064)

Korkmazer E \& Solak N 2014 Correlation between inflammatory markers and insulin resistance in pregnancy. Journal of Obstetrics and Gynaecology 35 142-145. (doi:10.3109/01443615.2014.948408)

Ku SY, Choi YM, Suh CS, Kim SH, Kim JG, Moon SY \& Lee JY 2002 Effect of gonadotropins on human endometrial stromal cell proliferation in vitro. Archives of Gynecology and Obstetrics 266 223-228. (doi:10.1007/ s00404-002-0292-9)

Loosfelt H, Misrahi M, Atger M, Salesse R, Vu Hai-Luu Thi MT, Jolivet A, Guiochon-Mantel A, Sar S, Jallal B, Garnier J et al. 1989 Cloning and sequencing of porcine LH-hCG receptor cDNA: variants lacking transmembrane domain. Science 245 525-528. (doi:10.1126/science. 2502844)

McFarland KC, Sprengel R, Phillips HS, Kohler M, Rosemblit N, Nikolics K, Segaloff DL \& Seeburg PH 1989 Lutropin-choriogonadotropin receptor: an unusual member of the $\mathrm{G}$ protein-coupled receptor family. Science 245 494-499. (doi:10.1126/science.2502842)

Merviel P, Muller F, Guibourdenche J, Berkane N, Gaudet R, Breart G \& Uzan S 2001 Correlations between serum assays of human CG (hCG) and human placental lactogen (hPL) and pre-eclampsia or intrauterine growth restriction (IUGR) among nulliparas younger than 38 years. European Journal of Obstetrics, Gynecology, and Reproductive Biology 95 59-67. (doi:10.1016/S0301-2115(00)00370-5)

Pierce JG \& Parsons TF 1981 Glycoprotein hormones: structure and function. Annual Review of Biochemistry 50 465-495. (doi:10.1146/ annurev.bi.50.070181.002341)

Rao Ch V 2001 An overview of the past, present, and future of nongonadal LH/hCG actions in reproductive biology and medicine. Seminars in Reproductive Medicine 19 7-17. (doi:10.1055/s-2001-13906)

Rao Ch V, Li X, Manna SK, Lei ZM \& Aggarwal BB 2004 Human chorionic gonadotropin decreases proliferation and invasion of breast cancer MCF-7 cells by inhibiting NF- $\kappa$ B and AP-1 activation. Journal of Biological Chemistry 279 25503-25510. (doi:10.1074/jbc.M400683200)

Rotter V, Nagaev I \& Smith U 2003 Interleukin-6 (IL-6) induces insulin resistance in 3T3-L1 adipocytes and is, like IL-8 and tumor necrosis factor- $\alpha$, overexpressed in human fat cells from insulin-resistant subjects. Journal of Biological Chemistry 278 45777-45784. (doi:10.1074/ jbc.M301977200)

Ryan EA \& Enns L 1988 Role of gestational hormones in the induction of insulin resistance. Journal of Clinical Endocrinology and Metabolism 67 341-347. (doi:10.1210/jcem-67-2-341)

Sartipy P \& Loskutoff DJ 2003 Monocyte chemoattractant protein 1 in obesity and insulin resistance. PNAS 100 7265-7270. (doi:10.1073/ pnas.1133870100)

Segaloff DL \& Ascoli M 1993 The lutropin/choriogonadotropin receptor... 4 years later. Endocrine Reviews 14 324-347. (doi:10.1210/edrv-14-3-324)

Shimomura I, Funahashi T, Takahashi M, Maeda K, Kotani K, Nakamura T, Yamashita S, Miura M, Fukuda Y, Takemura K et al. 1996 Enhanced expression of $P A I-1$ in visceral fat: possible contributor to vascular disease in obesity. Nature Medicine 2 800-803. (doi:10.1038/nm0796-800)

Sivan E, Whittaker PG, Sinha D, Homko CJ, Lin M, Reece EA \& Boden G 1998 Leptin in human pregnancy: the relationship with gestational hormones. American Journal of Obstetrics and Gynecology 179 1128-1132. (doi:10.1016/S0002-9378(98)70118-8)

Takahashi K, Mizuarai S, Araki H, Mashiko S, Ishihara A, Kanatani A, Itadani H \& Kotani H 2003 Adiposity elevates plasma MCP-1 levels leading to the increased CD11b-positive monocytes in mice. Journal of Biological Chemistry 278 46654-46660. (doi:10.1074/jbc. M309895200)

Watson RT, Kanzaki M \& Pessin JE 2004 Regulated membrane trafficking of the insulin-responsive glucose transporter 4 in adipocytes. Endocrine Reviews 25 177-204. (doi:10.1210/er.2003-0011)

Wolf M, Sauk J, Shah A, Vossen Smirnakis K, Jimenez-Kimble R, Ecker JL \& Thadhani R 2004 Inflammation and glucose intolerance: a prospective study of gestational diabetes mellitus. Diabetes Care 27 21-27. (doi:10.2337/diacare.27.1.21)

Yuan M, Konstantopoulos N, Lee J, Hansen L, Li ZW, Karin M \& Shoelson SE 2001 Reversal of obesity- and diet-induced insulin resistance with salicylates or targeted disruption of Ikk $\beta$. Science 293 1673-1677. (doi:10.1126/science.1061620)

Zygmunt M, Herr F, Keller-Schoenwetter S, Kunzi-Rapp K, Munstedt K, Rao CV, Lang U \& Preissner KT 2002 Characterization of human chorionic gonadotropin as a novel angiogenic factor. Journal of Clinical Endocrinology and Metabolism 87 5290-5296. (doi:10.1210/jc.2002020642)

Received in final form 30 December 2014

Accepted 14 January 2015 http://jme.endocrinology-journals.org

DOI: 10.1530/JME-14-0284
(C) 2015 Society for Endocrinology Printed in Great Britain
Published by Bioscientifica Ltd 